\title{
DERIVING EMPIRICAL DEFINITIONS OF SPATIAL LABOR MARKETS: THE ROLES OF COMPETING VERSUS COMPLEMENTARY GROWTH*
}

\author{
Romana Khan \\ Kellogg Graduate School of Management, Northwestern University, Evanston IL \\ 60208, U.S.A. E-mail:pfo@iastate.edu

\section{Peter F. Orazem and Daniel M. Otto} \\ Department of Economics, Iowa State University, Ames IA 50011, U.S.A. E-mail: \\ pfo@iastate.edu,dmotto@econ.iastate.edu
}

\begin{abstract}
If economic growth elsewhere raises an individual's earning prospects relative to his present location, then the individual will move. However, if the individual can exploit economic growth elsewhere by commuting, he will not need to move to gain from the expansion. County-level data from eight states in the Midwest over the period 1969-1994 are used to show that local county population responds positively to own-county economic growth, economic growth in the adjacent county, and economic growth two counties away. The magnitude of the effect decreases as distance from the county increases, and turns negative beyond a three county radius.
\end{abstract}

\section{INTRODUCTION}

All fifty states of the United States have publicly sponsored economic development efforts designed to attract new firms. In principle, each state competes with 49 others in attracting new firms, offering tax incentives, lowinterest or forgivable loans, worker training grants, and other inducements. Similarly, individual communities, through chambers of commerce or local economic development agencies, attempt to attract new firms, sometimes competing with other communities in the same state. ${ }^{1}$ However, it is not clear, that all economic gains in one community are at the expense of other communities.

*We thank Wally Huffman, William Kennedy, and three referees for useful comments. Donna Otto prepared the manuscript. Journal Paper No. J- 19324 of the Iowa Agriculture and Home Economics Experiment Station, Ames, Iowa, Project No. 340, and supported by Match Act and State of Iowa funds.

Received April 1999; revised October 2000; accepted February 2001.

${ }^{1}$ Research on whether these incentives actually alter the competitive positions of states and cities, and influence the firm location decision is inconclusive. Most recently, Fisher and Peters (1998) find that discretionary tax and nontax incentives do not change the competitive positions of states and cities. Although areas with the poorest incentives and highest taxes will be eliminated from consideration in firm location decisions, in most cases the impact of incentives is uncertain.

(C) Blackwell Publishers 2001.

Blackwell Publishers, 350 Main Street, Malden, MA 02148, USA and 108 Cowley Road, Oxford, OX4 1JF, UK. 
In particular, if one town succeeds in attracting new jobs, municipalities within commuting distance may benefit rather than be harmed by the first community's good fortune. On the other hand, if the two municipalities are farther apart, workers in one location will have to move to the other city in order to benefit from that city's economic expansion. This suggests that the limits of a locality's labor market can be established by whether its population rises or falls in response to economic growth in its surrounding communities.

Many papers have documented that population growth and employment growth within a metropolitan area are jointly determined. For example, Greenwood, Hunt, and McDowell (1986) found that an increase of two jobs increases population by one, and that when population rises by two, there is an average increase of one job. Other papers exploring the joint determination of local population and employment growth include Boarnet (1994); Carlino and Mills (1987); and Clark and Murphy (1996). Less is known about the impacts of employment growth in one community on population growth elsewhere.

There has been increasing interest in how these economic activities spill over to other jurisdictions. Much of the current research on interregional interactions builds on Roback's (1992) pioneering model that allows interregional amenity differences to be priced into interregional differences in wages and land rents. Early applications of these models were concerned with processes of suburbanization, urban decline, and overall metropolitan growth. In this interregional framework, population and economic activity in a metropolitan region adjust to allow for an efficient distribution of firms and individuals (Adams et al., 1994; Benabou, 1993; Henry, Barkley, and Bao, 1997). Other applications of this interregional modeling approach have examined the local versus regional effects of amenities, (Blomquist, Berger, and Hoehn, 1988; Voith, 1991, 1993) and the bidirectional effects of public investments and economic activities in cities and suburbs (Voith, 1998). In each of these studies, economic activities occurring in one region are found to generate broader regional effects and economic adjustments, rather than only occurring locally.

Following the work of Alonso (1964), Mills (1967), and Muth (1969), we know that equilibrium wages and housing prices should decline as distance from an urban core increases. Empirical work by McMillen and Singell (1992) and White (1988) confirm the existence of these housing price and wage gradients. This evidence suggests that an increase in labor demand in a central city should raise incentives to locate in both the center and the periphery. The equilibrium results suggest that there exists some maximum distance from the center beyond which economic growth in the center will no longer raise population in the periphery and will begin to decrease the periphery's population. ${ }^{2}$ However, although the

${ }^{2}$ This has been termed the spread-backwash model from regional economics. Gaile's (1980) review of that literature concluded that empirical work to date on the spread-backwash model had been disappointing. The Henry, Barkley, and Bao (1997) study suggests that empirical work since the Gaile paper was published have continued to provide little support for the spread-backwash model, although their own paper did find modest support.

(c) Blackwell Publishers 2001. 
existence of these spillover growth effects have been demonstrated empirically, the limits of that critical distance have not been well established.

This study builds on the earlier work by documenting the magnitude and the limits of cross-county complementary economic growth. Rather than tying the model to the existence of a definable central city and its surroundings, the theoretical model applies generally to any community and its neighbors. The model is tested with county-level data from eight states in the Midwest over the period 1969-1994. County population is explained by county wage growth, wage growth in adjacent and nonadjacent counties, and national wage growth. The specification is repeated using information on job growth and on wage bill growth (wages times jobs). Empirical estimates correct for possible simultaneous determination of local economic growth measures and local population.

The results are quite consistent, regardless of how economic growth is measured or what additional controls are added for local amenities or fiscal policies. Local county population responds positively to own-county economic growth, economic growth in the adjacent county, and even economic growth two counties away. The magnitude of the effect decreases as distance from the county increases. On the other hand, economic growth beyond a distance of two counties lowers population, presumably because change of residence is required if the local population is to benefit from distant economic growth. The pattern of results differs depending on the size of the county. In particular, if economic growth is uniform across all counties in the Midwest, the least populous counties will lose population while the most populous counties will get larger.

These results suggest that economic growth is complementary within a three-county radius and competitive outside that radius. Presumably then, it is wasteful for one county's economic development efforts to attempt to compete with the efforts of neighboring counties or those counties' neighbors. Instead, cooperative efforts to attract a business to the area would still insure at least partial benefit to all counties in the region, regardless of which county the firm selects.

\section{A MODEL OF POPULATION GROWTH}

This section develops a stylized, estimable model of county population growth in a county, 0 , which incorporates the effects of economic growth in other counties. To begin, assume that a representative agent's indirect utility from residing in county 0 at time $t$ depends on income opportunities available in the county and its surroundings, and on the hedonic value of living amenities in the county, $A_{0 t}$. The local amenities include local meteorological and topographic attributes that do not vary over time, although the hedonic value of those attributes may vary over time.

Income opportunities in county 0 include working in the local county at real wage $W_{0, t}$ with no commuting cost or working in another county $k$, and absorbing commuting costs $C_{k, t}$ in exchange for receiving wages $W_{k, t}$. The indirect utility of the representative agent living in county 0 is specified as $U_{0, t}\left(W_{0, t}, W_{k, t}, C_{k, t}\right.$, 
$A_{0, t}$, where $W_{0, t}$ is the average real wage per job in county 0 at time $t, W_{k, t}$ is a vector of real wages, and $\boldsymbol{C}_{k, t}$ is a vector of commuting costs for counties within commuting distance, $k=1, \ldots, K$. Similarly, for an individual living in county 0 , the utility associated with residing in another county $m$ outside commuting distance can be expressed as $U_{m, t}\left(W_{m, t}, M_{m, t}, A_{m, t}\right)$ where $W_{m, t}$ is the prevailing real market wage, $M_{m, t}$ is the cost of moving from county 0 to county $m$, and $A_{m, t}$ is the value of amenities.

At time $t$, an individual will want to maximize utility by deciding where to locate based on a comparison of utilities across all counties, $U_{i, t}, i=0, \ldots N$. This decision is written as

$$
U=\operatorname{Max}\left(U_{0, t}, U_{1, t}, \ldots, U_{\mathrm{N}, \mathrm{t}}\right)
$$

where $U_{i, t}$ is the utility for county $i$, and $N$ is the number of counties. Consequently, the utility of an individual in any county can be expressed as a function of all county wage levels, moving and commuting costs between counties, and local amenities. ${ }^{3}$

$$
\begin{gathered}
U_{t}=\operatorname{Max}\left(U_{0, t}, U_{1, t}, \ldots, U_{\mathrm{N}, \mathrm{t}}\right) \\
=U_{t}\left(W_{0, \mathrm{t}}, A_{0, t}, W_{1, t}, \ldots W_{\mathrm{N}, t}, C_{1, t}, \ldots C_{\mathrm{N}, t}, M_{1, t}, \ldots M_{\mathrm{N}, t}, A_{1, t}, \ldots A_{\mathrm{N}, t}\right)
\end{gathered}
$$

Suppose an individual initially resides in county 0 . Equation (1) implies that at any time $t$, an individual will move to county $n$ if conditions change so that $\operatorname{Max}\left(U_{0, t}, U_{1, t} \ldots U_{N, t}\right)=U_{n, t}$. Thus, $P_{0, t}$, the population level in county 0 at time $t$, can be expressed as a function of the utility levels across all counties, which are in turn a function of the wages, commuting costs, and moving costs for all counties. In notation,

$$
P_{0, t}=G\left(U_{0, t}, \ldots, U_{\mathrm{N}, \mathrm{t}}\right)
$$

To make Equation (2) tractable empirically, we need to specify functional forms for $G$ and $U_{j, t}$. Assuming a Cobb-Douglas form for $U_{j, t}$, the utility functions will be

$$
\begin{gathered}
U_{j, t}\left[W_{0, t}, W_{1, t}, \ldots W_{N, t}, C_{1, t}, \ldots C_{N, t}, M_{1, t}, \ldots M_{N, t}, A_{0, t}, \ldots A_{N, t}\right] \\
=W_{0, t}^{\gamma_{0}} A_{0, t}^{\theta_{0}} \prod_{i=1}^{N} W_{i, t}^{\gamma_{i}} M_{i, t}^{\beta_{i}} C_{i, t}^{\delta_{i}} A_{i, t}^{\theta_{i}}
\end{gathered}
$$

where $\gamma_{i}>0$ are the relative weights on wages, $\beta_{i}<0$ are the relative utility weights on migration costs to county $\mathrm{i}, \delta_{i}<0$ are the relative weights on commuting costs, and $\theta_{i}^{>} 0$ are the relative weights on local amenities in the

\footnotetext{
${ }^{3}$ Later we will substitute local jobs and local income for local wages in our utility function. For the most part, our results are quite similar regardless of how spatially differentiated local labor market growth is measured.

(c) Blackwell Publishers 2001.
} 
utility function. We assume that $G($.$) in Equation (2) is proportional to the level$ of utility, so that using Equation (3)

$$
P_{0, t}=\alpha W_{0, t}^{\gamma_{0}} A_{0, t}^{\theta_{0}} \prod_{i=1}^{N} W_{i, t}^{\gamma_{i}} M_{i, t}^{\beta_{i}} C_{i, t}^{\delta_{i}} A_{i, t}^{\theta_{i}}
$$

where $\alpha$ is a constant of proportionality.

Taking natural logarithms of Equation (4) and differencing between periods $t$ and $t+k$, we get

$$
\begin{gathered}
\ln \left(P_{0, t+k} / P_{0, t}\right)=\sum_{i=0}^{N} \gamma_{i} \ln \left(W_{i, t+k} / W_{i, t}\right)+\sum_{i=1}^{N} \beta_{i} \ln \left(M_{i, t+k} / M_{i, t}\right) \\
+\sum_{i=1}^{N} \delta_{i} \ln \left(C_{i, t+k} / C_{i, t}\right)+\sum_{i=0}^{N} \theta_{i} \ln \left(A_{i, t+k} / A_{i, t}\right)
\end{gathered}
$$

Our primary interest is in the coefficients on spatially distributed economic growth. However, we must first specify how we can control for the other factors in Equation (5).

Moving costs will be dominated by factors that are common across counties such as fuel and transportation equipment. Although there will be variation in these costs across counties, all $N$ county moving costs are included in the utility function. Consequently, there will be little cross-sectional variation in moving costs although there will be variation over time. This justifies a simplification of the moving cost formulation for county 0 , as

$$
\sum_{i \neq j} \beta_{i} \ln \left(\frac{M_{i, t+k}}{M_{i, t}}\right)=\bar{M}+e_{0, t}^{M}
$$

where $e_{j, t}^{M}$ is an error term with mean zero.

Changes in commuting costs will reflect changes in the value of time in the local labor market. Transportation costs may also change at different rates in small towns versus urban areas. Therefore, we specify the commuting cost from county 0 to county $1 \mathrm{as}^{4}$

$$
\ln \left(\frac{C_{1, t+k}}{C_{1, t}}\right)=\Delta_{U} U R B A N+\Delta_{P} \ln P_{0, t}+\Delta_{W_{1}} \ln \left(\frac{W_{1, t+k}}{W_{1, t}}\right)+e_{0, t}^{C_{1}}
$$

The coefficient on wage growth $\Delta_{W_{i}}$ would be expected to become more negative as distance from county 0 increases.

${ }^{4}$ Use of initial population level rather than the change in population also avoids a simultaneity problem with the dependent variable.

C) Blackwell Publishers 2001. 
The change in the value of local amenities for county 0 are specified as

(8) $\theta_{0} \ln \left(\frac{A_{0, t+k}}{A_{0, t}}\right)=\Theta_{A} A M E N I T Y_{j}+\Theta_{U} U R B A N_{j}+\Theta_{P} \ln P_{0, t}+\Theta_{R} \ln R_{0, t}$

where $A M E N I T Y_{j}$ is an index for the quality of local weather and topographic features, and $R_{0, t}$ is the rental cost of housing. To the extent that valued local amenities are capitalized in rental costs, the net impact of the amenities will be diminished.

All $N$ other local amenities enter Equation (6), but there will be little difference in the weighted average of these amenities across counties as $N$ gets large. Therefore, we approximate

$$
\sum_{i \neq 0} \theta_{i} \ln \left(\frac{A_{i, t+k}}{A_{i, t}}\right)=\bar{A}+e_{0, t}^{A}
$$

Inserting Equations (6)-(9) into Equation (5), we get the estimable form

$$
\begin{aligned}
& \text { (10) } \ln \left(P_{0, t+k} / P_{0, t}\right)=\psi_{0}+\gamma_{0} \ln \left(W_{0, t+k} / W_{0, t}\right)+\Gamma_{1} \ln \left(W_{1, t+k} / W_{1, t}\right)+\ldots+\Gamma_{N} \ln \left(W_{N, t+k} / W_{N, t}\right) \\
& +\Theta_{A} A M E N I T Y_{0}+\psi_{U} U R B A N_{0}+\psi_{P} \ln P_{0, t}+\theta_{R} \ln R_{0, t}+e_{0, t}
\end{aligned}
$$

where

$$
\psi_{0}=\bar{M}+\bar{A} ; \Gamma_{i}=\left(\gamma_{i}+\delta_{i} \Delta_{W_{i}}\right) ; \psi_{U}=\Theta_{U}+\Delta_{U} \sum_{i} \delta_{i} ; \psi_{P}=\Theta_{P}+\Delta_{P} \sum_{i} \delta_{i}
$$

and

$$
e_{0, t}=e_{0, t}^{M}+e_{o, t}^{A}+\sum_{i=1} e_{o, t}^{C_{i}}
$$

The value of $\gamma_{0}$ determines how the population responds to own-county wage growth. The signs of $\Gamma_{i}$ indicate whether wages in a county $i$ raise or lower utility in the own county relative to utility elsewhere. We expect wages in the own county will raise $U_{0, t}$, holding other county wages constant, so that $\gamma_{0}>0$. However, $\Gamma_{i}=\gamma_{i}+\delta_{i} \Delta_{W_{i}}$ can be positive or negative. While wages alone would raise utility so that $\gamma_{i}>0$, commuting costs would lower utility so that $\delta_{i} \Delta_{W_{i}}<0$. As distance from county 0 to county $i$ increases, $\delta_{i} \Delta_{W_{i}}$ becomes more negative. We would also expect that more distant wage growth would be discounted more heavily so that $\gamma_{i}$ becomes less positive. Consequently, as distance from county 0 increases, $\Gamma_{i}$ should get smaller and eventually turn negative.

The signs on $\Gamma_{i}$ for adjacent and nonadjacent counties are relevant for understanding linkages between counties in terms of complementary versus competing growth effects. The only way $W_{i}$ can increase $U_{0, t}$ relative to utility 
elsewhere is if the own commute to county $i$ is cost-effective, which in turn requires that $\Gamma_{i}>0$. Therefore, a positive value of $\Gamma_{i}$ implies the existence of complementary growth between counties 0 and $i$. A negative value for $\Gamma_{i}$ means that the disutility of the commute to $i$ exceeds the value of the wage. This indicates the presence of competing growth between counties 0 and $i$. Workers in county 0 would have to migrate in order to benefit from wages in county $i$.

\section{EMPIRICAL STRATEGIES}

We estimate Equation (10) using four measures of spatially distributed wage growth: $\ln \left[W_{0, t+k} / W_{0, t}\right]$ for the own county, $\ln \left(W_{1, t+k} / W_{1, t}\right)$ for an adjacent county, $\ln \left(W_{2, t+k} / W_{2, t}\right)$ for wage growth in a nonadjacent county (two counties away from $j)$, and $\ln \left(W_{s, t+k} / W_{s, t}\right)$ for wage growth in the rest of the state that is orthogonal to wage growth in the two-county radius of county j. ${ }^{5}$ Earlier versions using wage growth three counties away rather than the state-wide measure yielded similar results to those reported herein.

Local population growth and local economic growth are undoubtedly determined simultaneously. Consequently, we specified instruments for own-county wage growth. We selected instruments based on a stylized representation of a local labor market model subject to lagged adjustments. Carrington (1996) found that it took two years for wages and employment to adjust to labor demand shocks associated with the Alaska pipeline. Blanchflower and Oswald (1994) report a one-to-two-year lagged effect of unemployment rates on regional and state wages.

Such a model is illustrated in Figure 1. Real wages $W_{t}$ and employment, $J_{t}$ are determined by labor supply and demand conditions, but with a lag. To ease exposition, we standardize labor market size by dividing employment by population size. The employment rate, $J_{t} / P_{t}$ varies between zero and unity. Given prevailing demand and supply conditions for labor $J_{t} / P_{t}$ reaches a maximum possible value $J_{t}^{e} / P_{t}$ when the wage is at equilibrium $W_{t}^{e}$. Any departure from equilibrium will result in a lower value for $J_{t} / P_{t}$, regardless of whether the wage is above or below equilibrium.

Suppose that the employment rate is given by $J_{t}^{1} / P_{t}$ in Figure 1 . If the wage is $W_{t}^{0}$ so that we have excess supply of labor, there will be downward pressure on future wages. If the wage is $W_{t}^{1}$, there is excess demand for labor so that wages will rise in the future. As a consequence, holding $J_{t} / P_{t}$ constant, high values of $W_{t}$ will lead to lower values of $W_{t+k}$ as the market tends toward equilibrium. Because low levels of $J_{t} / P_{t}$ imply a departure from equilibrium

\footnotetext{
${ }^{5}$ To reduce potential problems of simultaneity, we chose the largest county 1,2 , and 3 counties away rather than averaging across all counties. Wages in the largest county would be less affected by population changes in county 0 than would the average county. Job information flows and commuting linkages should be most established between county 0 and its largest neighboring county than with its smaller neighboring counties.
}

(C) Blackwell Publishers 2001. 


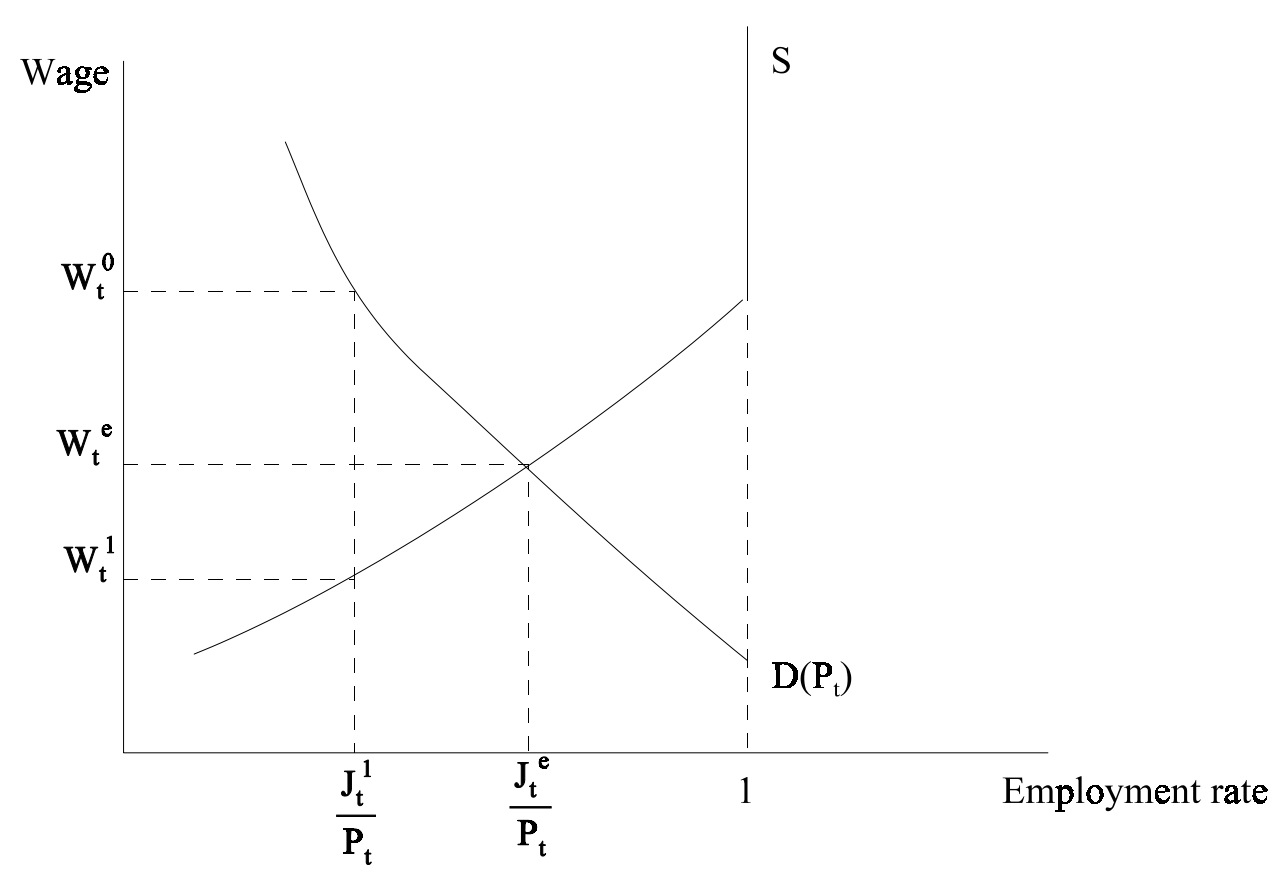

FIGURE 1: Local Labor Demand and Supply.

employment regardless of whether the wage is above or below equilibrium, we cannot predict the effect of $J_{t} / P_{t}$ on future wages.

On the other hand, holding $W_{t}$ constant, low values of $J_{t} / P_{t}$ will lead to higher future employment as the market adjusts toward equilibrium. Therefore, we would expect low values of $J_{t} / P_{t}$ to signal higher values of $J_{t+k}$. As is clear from Figure 1, we cannot sign the relationship between $W_{t}$ and $J_{t+k}$. Both wages that are above equilibrium $\left(W_{t}^{0}\right)$ and wages that are below equilibrium $\left(W_{t}^{1}\right)$ would imply an increase in future employment as the labor market adjusts toward equilibrium.

This simple sticky-wage model of local labor markets suggests that one can forecast future wage and employment growth in a county using information on wages and employment rates in the current period. We settled on the following empirical formulation

$$
\begin{aligned}
& \ln \left(W_{0, t+k} / W_{0, t}\right)=a_{0}+a_{1} \ln \left(W_{0, t}\right)+a_{2} \ln \left(J_{t} / P_{t}\right)+a_{3} \ln \left(P_{t}\right)+a_{4}\left[\ln \left(P_{t}\right)\right]^{2}+a_{5} U R B A N+e_{t}^{W} \\
& \ln \left(J_{0, t+k} / J_{0, t}\right)=b_{0}+b_{1} \ln \left[W_{0, t}\right]+b_{2} \ln \left(J_{t} / P_{t}\right)+b_{3} \ln \left(P_{t}\right)+b_{4}\left[\ln \left(P_{t}\right)\right]^{2}+b_{5} U R B A N+e_{t}^{J}
\end{aligned}
$$


$\ln \left(P_{t}\right),\left[\ln \left(P_{t}^{2}\right)\right]^{2}$ and $U R B A N$ are exogenous shifters of the demand and supply curves. ${ }^{6}$ Given the earlier discussion, the model predicts that $a_{1}<0$ and $b_{2}<0$. The theory does not generate predictions about the signs of the other parameters.

\section{DATA}

The primary data source is the county-level employment, population and earnings information compiled by the Bureau of Economic Analysis over the years 1969 to 1994. The states included in the sample are Iowa, Kansas, South Dakota, Nebraska, Illinois, Wisconsin, Minnesota, and Missouri. These states were chosen because a significant proportion of the population resided in nonrural, nonmetropolitan locations. This assures us of considerable variation in county population. There were a total of 737 counties. We designate a county as $U R B A N$ if either it or an adjacent county has a population above 50,000 in 1969. By that criteria, 277 counties were urban. Counties were of comparable geographic size across states and were arranged in a similar grid pattern. Comparable grid patterns make it more sensible to assume equal population supply responses to economic growth one or two counties away.

We divide the time period into five subperiods of five years each. The base periods were 1969, 1974, 1979, 1984, and 1989. The growth rates for population and average wage per job were measured over five year intervals: 1969-1974, 1974-1979, 1979-1984, 1984-1989, and 1989-1994. This yielded five time periods for every state, bringing the total number of observations to 3,685. A five-year period should provide a sufficiently long time to capture the long run population response to changes in local and surrounding labor markets. It also sidesteps potential complications due to short-term common cyclical shocks that could exaggerate the positive correlation between local wages and employment.

Population is defined as the total number of people living in the county. Jobs are defined as the total number of people working in the county. It is important to emphasize the distinction between the measures of population and employment. County population includes those living in the county, but not necessarily working in the county. Wage and employment data are from all people working in the county including those who commute to the county but live elsewhere, and excluding those who live in the county but work elsewhere. In this way, we are able to separate labor market variables from population responses.

The sample statistics are reported in Table 1. Population growth has been modest over the period, averaging one-half of one percent every five years. However, counties in the lowest quartile population over the period shrank an average of 2.7 percent per five-year period, and the most populated counties

${ }^{6}$ Higher population will shift labor supply to the right as well as create a demand for labor to provide local goods and services. To the extent that urban areas have lower commuting or job search costs or enjoy agglomeration economies that make labor more productive, we would observe demand and supply shifts as we move from rural to urban markets.

(C) Blackwell Publishers 2001. 
TABLE 1: Selected Sample Statistics, by County Population Quartiles ${ }^{a}$

\begin{tabular}{|c|c|c|c|c|}
\hline \multirow[t]{3}{*}{ Variables } & \multicolumn{4}{|c|}{ Mean and Standard Deviations } \\
\hline & \multirow[b]{2}{*}{ Entire Sample } & \multicolumn{3}{|c|}{ Population Groups } \\
\hline & & $\begin{array}{l}\text { Lower Quartile } \\
\qquad(=8,000)\end{array}$ & Middle Quartiles & $\begin{array}{l}\text { Upper Quartile } \\
\quad(=29,600)\end{array}$ \\
\hline $\ln \left(P_{0, t+5} / P_{0, t}\right):$ Population Growth ${ }^{\mathrm{c}}$ & $\begin{array}{c}0.005 \\
(0.06)\end{array}$ & $\begin{array}{r}-0.027 \\
(0.06)\end{array}$ & $\begin{array}{c}0.008 \\
(0.06)\end{array}$ & $\begin{array}{c}0.033 \\
(0.057)\end{array}$ \\
\hline $\ln \left(W_{0, t+5} / W_{0, t}\right):$ Real Wage Growth ${ }^{\mathrm{c}, \mathrm{d}}$ & $\begin{array}{c}-0.005 \\
(0.07)\end{array}$ & $\begin{array}{c}-0.003 \\
(0.09)\end{array}$ & $\begin{array}{c}-0.004 \\
(0.07)\end{array}$ & $\begin{array}{c}-0.010 \\
(0.05)\end{array}$ \\
\hline $\ln \left(J_{0, t+5} / J_{0, t}\right):$ Job Growth ${ }^{\mathrm{c}}$ & $\begin{array}{c}0.071 \\
(0.12)\end{array}$ & $\begin{array}{c}0.036 \\
(0.13)\end{array}$ & $\begin{array}{c}0.079 \\
(0.12)\end{array}$ & $\begin{array}{c}0.089 \\
(0.10)\end{array}$ \\
\hline $\ln \left(I_{0, t+5} / I_{0, t}\right):$ Wage Bill Growth ${ }^{\mathrm{c}, \mathrm{d}}$ & $\begin{array}{c}0.065 \\
(0.16)\end{array}$ & $\begin{array}{c}0.032 \\
(0.18)\end{array}$ & $\begin{array}{c}0.075 \\
(0.17)\end{array}$ & $\begin{array}{c}0.079 \\
(0.13)\end{array}$ \\
\hline$P_{t}:$ Population $\left({ }^{(} 000\right)^{\mathrm{c}}$ & $\begin{array}{c}43.8 \\
(212.6)\end{array}$ & $\begin{array}{c}4.83 \\
(2.03)\end{array}$ & $\begin{array}{l}16.0 \\
(5.70)\end{array}$ & $\begin{array}{c}138.3 \\
(410.7)\end{array}$ \\
\hline$\left(J_{t} / P_{t}\right):$ Employment Rate ${ }^{\mathrm{c}}$ & $\begin{array}{c}0.32 \\
(0.10)\end{array}$ & $\begin{array}{c}0.28 \\
(0.07)\end{array}$ & $\begin{array}{c}0.30 \\
(0.09)\end{array}$ & $\begin{array}{c}0.40 \\
(.10)\end{array}$ \\
\hline$W_{t}$ : Real Annual Wage ('000) ${ }^{\mathrm{c}, \mathrm{d}}$ & $\begin{array}{c}12.80 \\
(2.54)\end{array}$ & $\begin{array}{l}12.2 \\
(2.37)\end{array}$ & $\begin{array}{l}12.81 \\
(2.47)\end{array}$ & $\begin{array}{l}13.39 \\
(2.72)\end{array}$ \\
\hline$J_{t}:$ Jobs $\left({ }^{(} 000\right)^{\mathrm{c}}$ & $\begin{array}{c}18.9 \\
(109.8)\end{array}$ & $\begin{array}{c}1.35 \\
(0.66)\end{array}$ & $\begin{array}{c}5.0 \\
(2.9)\end{array}$ & $\begin{array}{c}64.5 \\
(213.1)\end{array}$ \\
\hline \multicolumn{5}{|l|}{$U R B A N$ : Own or Adjacent } \\
\hline Population over $50,000^{\mathrm{c}}$ & $\begin{array}{c}0.38 \\
(0.48)\end{array}$ & $\begin{array}{c}0.09 \\
(0.29)\end{array}$ & $\begin{array}{c}0.34 \\
(0.47)\end{array}$ & $\begin{array}{c}0.74 \\
(0.44)\end{array}$ \\
\hline \multicolumn{5}{|l|}{ AMENITY: U.S.D.A. Natural } \\
\hline Amenity Scale $\mathrm{e}^{\mathrm{e}}$ & $\begin{array}{c}2.74 \\
(0.68)\end{array}$ & $\begin{array}{c}2.92 \\
(0.64)\end{array}$ & $\begin{array}{c}2.68 \\
(0.69)\end{array}$ & $\begin{array}{c}2.67 \\
(0.68)\end{array}$ \\
\hline $\ln \left(R_{t}^{H}\right)$ Gross Rental Price ${ }^{\mathrm{f}}$ & $\begin{array}{c}5.33 \\
(0.47)\end{array}$ & $\mathrm{b}$ & $\mathrm{b}$ & $\mathrm{b}$ \\
\hline
\end{tabular}

\footnotetext{
${ }^{\mathrm{a}}$ Standard errors in parentheses.

${ }^{\mathrm{b}}$ State-level variable which does not vary by county.

${ }^{\mathrm{c}}$ Bureau of Economic Analysis: county-level data on income, employment and population.

${ }^{\mathrm{d}}$ Deflated by the Consumer Price Index for Urban Consumers.

${ }^{\mathrm{e}}$ U.S.D.A.-E.R.S.: natural amenities county-level data file.

${ }^{\mathrm{f}}$ U.S. Census of Housing: median real contract rent plus the cost of utilities.
}

grew an average of 3.3 percent every five years. Wage growth did not vary much between counties, although there was a clear wage gap between urban and rural counties. Workers in intermediate counties received about a 5 percent premium and those in the largest counties received a 10 percent premium over the pay in the least populous counties. The clear advantage in the largest counties was in job and wage bill growth and not wage growth per se. Both measures of economic growth were around 2.5 times higher in the upper quartile counties than in the lowest quartile counties. Employment rates were also highest in the largest counties. This implies that job growth in smaller counties can be accommodated 
by the existing local population, whereas job growth in larger counties will more likely require inmigration of new workers. Later on, we will find that population growth is indeed most responsive to economic growth in the biggest counties and least responsive in the smallest counties.

$A M E N I T Y$ is an index of environmental quality compiled by the U.S.D.A. The index, which ranges from 1 to 6 , rates an area higher for warm Januarys, mild Julys, sunny days in January, low July humidity, varied topography, and percentage of water coverage. There is some variation across counties, with less populated areas rated somewhat higher on average than more populated counties. Housing costs were measured by the real gross rental price, which includes utility costs as well as rent. These are reported in the Census of Housing for the state. For the intercensus years, these measures were interpolated assuming a constant growth rate.

\section{POPULATION GROWTH FROM SPATIALLY DIFFERENTIATED WAGE GROWTH}

The results of two-stage generalized least squares (GLS) estimation of Equation (10) are presented in Table 2. Twenty-two percent of the variation in population growth is explained by the model. The coefficients in the population growth equation are interpretable alternatively as elasticities of utility with respect to wage levels, net of commuting costs, or as elasticities of population growth with respect to wage growth in each area. As one would expect, increased wage growth in a county raises the utility from residence in that county and attracts migrants. The estimates in column one imply that a 10 percent increase in local county wage growth results in a 7.2 percent increase in local population growth. The coefficients $\Gamma_{1}$ and $\Gamma_{2}$ indicate how wage growth in the adjacent and nonadjacent counties affect population growth in the own county. Positive $\Gamma_{1}$ indicates complementary growth effects between adjacent counties. The coefficient implies that 10 percent wage growth one county away will raise local county population by just over 1 percent. $\Gamma_{2}$ is also positive but smaller still, so that a 10 percent wage growth two counties away raises local county population by less than 1 percent. These results suggest that the relevant county labor market as defined by population responses to spatially differentiated wage growth includes the home county, adjacent counties, and the counties adjacent to them. Wage growth outside that range lowers home county population, consistent with the presumption that wage growth outside the local labor market raises utility elsewhere relative to home county utility, and thus causes outmigration. ${ }^{7}$

The size of the local labor market varies with population size. As indicated by the test of structural equivalency, the null hypothesis that the coefficients are identical across the small, medium, and large counties was

\footnotetext{
${ }^{7}$ We also estimated the model using national wage growth in place of the state wage growth measure. The results were very similar.

(C) Blackwell Publishers 2001.
} 
TABLE 2: Regressions of Population Growth on Spatially Differentiated Wage Growth ${ }^{\mathrm{a}}$

\begin{tabular}{|c|c|c|c|c|c|}
\hline \multirow[t]{2}{*}{ Variables } & \multicolumn{4}{|c|}{ Estimated Coefficients and $t$-Ratios } & \multirow[b]{2}{*}{$\begin{array}{l}\text { Unrestricted } \\
\text { Full Sample }\end{array}$} \\
\hline & $\begin{array}{l}\text { Full } \\
\text { Sample }\end{array}$ & $\begin{array}{l}\text { Lower } \\
\text { Quartile }\end{array}$ & $\begin{array}{l}\text { Middle } \\
\text { Quartiles }\end{array}$ & $\begin{array}{l}\text { Upper } \\
\text { Quartile }\end{array}$ & \\
\hline \multicolumn{6}{|l|}{ Stage 2} \\
\hline$\gamma_{0}: \ln \left(W_{0, t+5} / W_{0, t}\right)^{\mathrm{b}}$ & $\begin{array}{l}0.718^{* *} \\
(5.38)\end{array}$ & $\begin{array}{c}-0.067 \\
(0.39)\end{array}$ & $\begin{array}{l}0.672^{* *} \\
(3.78)\end{array}$ & $\begin{array}{l}2.00 * * \\
(4.10)\end{array}$ & - \\
\hline$\Gamma_{1}: \ln \left(W_{1, t+5} / W_{1, t}\right)$ & $\begin{array}{l}0.105^{* *} \\
(5.34)\end{array}$ & $\begin{array}{c}0.015 \\
(0.039)\end{array}$ & $\begin{array}{l}0.105^{* *} \\
(3.98)\end{array}$ & $\begin{array}{l}0.262^{* * *} \\
(6.91)\end{array}$ & $\begin{array}{l}0.111^{* *} \\
(5.67)\end{array}$ \\
\hline$\Gamma_{2}: \ln \left(W_{2, t+5} / W_{2, t}\right)$ & $\begin{array}{l}0.078 * * \\
(3.81)\end{array}$ & $\begin{array}{l}0.158^{* *} \\
(3.39)\end{array}$ & $\begin{array}{l}0.052^{* *} \\
(1.99)\end{array}$ & $\begin{array}{c}0.054 \\
(1.33)\end{array}$ & $\begin{array}{l}0.084^{* *} \\
(4.10)\end{array}$ \\
\hline$\Gamma_{S}: \ln \left(W_{S, t+5} / W_{S, t}\right)^{\text {Residual }}$ & $\begin{array}{l}-0.305 * * \\
(7.86)\end{array}$ & $\begin{array}{l}-0.480^{* *} \\
(5.22)\end{array}$ & $\begin{array}{l}-0.247 * * \\
(4.81)\end{array}$ & $\begin{array}{l}-0.302^{* *} \\
(4.18)\end{array}$ & $\begin{array}{l}-0.298^{* *} \\
(7.68)\end{array}$ \\
\hline AMENITY & $\begin{array}{l}0.013^{* *} \\
(8.90)\end{array}$ & $\begin{array}{l}0.019^{* * *} \\
(6.24)\end{array}$ & $\begin{array}{l}0.017 * * \\
(8.16)\end{array}$ & $\begin{array}{l}0.006^{* *} \\
(2.11)\end{array}$ & $\begin{array}{l}0.015^{* *} \\
(10.1)\end{array}$ \\
\hline$U R B A N$ & $\begin{array}{l}0.018 * * \\
(8.08)\end{array}$ & $\begin{array}{l}0.017 * * \\
(3.02)\end{array}$ & $\begin{array}{l}0.011^{* *} \\
(4.17)\end{array}$ & $\begin{array}{l}0.026^{* *} \\
(6.28)\end{array}$ & $\begin{array}{l}.017 * * \\
(7.97)\end{array}$ \\
\hline $\ln \left(R_{t}^{H}\right)$ & $\begin{array}{l}-0.012^{* *} \\
(5.40)\end{array}$ & $\begin{array}{l}-0.013^{* *} \\
(2.96)\end{array}$ & $\begin{array}{l}-0.020 * * \\
(6.60)\end{array}$ & $\begin{array}{c}-0.006 \\
(1.36)\end{array}$ & $\begin{array}{l}-0.011^{* *} \\
(5.02)\end{array}$ \\
\hline $\ln \left(P_{t}\right)$ & $\begin{array}{l}0.016^{* *} \\
(14.3)\end{array}$ & $\begin{array}{l}0.011^{* *} \\
(2.74)\end{array}$ & $\begin{array}{l}0.033^{* *} \\
(9.27)\end{array}$ & $\begin{array}{l}-0.009 * * \\
(3.27)\end{array}$ & $\begin{array}{l}-0.039 * * \\
(12.4)\end{array}$ \\
\hline Constant & $\begin{array}{c}-0.014 \\
(1.12)\end{array}$ & $\begin{array}{l}0.012^{* *} \\
(2.74)\end{array}$ & $\begin{array}{c}-0.024 \\
(1.23)\end{array}$ & $\begin{array}{l}0.088^{* *} \\
(3.53)\end{array}$ & - \\
\hline $\mathrm{R}^{2}$ & 0.22 & 0.13 & 0.18 & 0.15 & \\
\hline \multicolumn{6}{|l|}{ Stage 1} \\
\hline$b_{1}: \ln \left(P_{t}\right)$ & $\begin{array}{c}0.003 \\
(1.00)\end{array}$ & $\begin{array}{c}0.011 \\
(0.55)\end{array}$ & $\begin{array}{c}-0.106 \\
(1.44)\end{array}$ & $\begin{array}{c}-0.014 \\
(1.06)\end{array}$ & - \\
\hline$b_{2}:\left[\ln \left(P_{t}\right)\right]^{2}$ & $\begin{array}{l}-0.0001 \\
(0.11)\end{array}$ & $\begin{array}{l}-0.0005 \\
(0.06)\end{array}$ & $\begin{array}{l}0.021^{* *} \\
(1.56)\end{array}$ & $\begin{array}{c}-0.002 \\
(1.38)\end{array}$ & $\begin{array}{l}-0.003^{* *} \\
(7.16)\end{array}$ \\
\hline$b_{3}: \ln \left(E_{t} / P_{t}\right)$ & $\begin{array}{l}-0.030^{* *} \\
(6.73)\end{array}$ & $\begin{array}{l}-0.048^{* *} \\
(4.35)\end{array}$ & $\begin{array}{l}-0.026^{* *} \\
(3.06)\end{array}$ & $\begin{array}{c}-0.009 \\
(1.10)\end{array}$ & $\begin{array}{l}-.022^{* *} \\
(4.95)\end{array}$ \\
\hline$b_{4}: \ln \left(W_{t}\right)$ & $\begin{array}{l}-0.025^{* *} \\
(3.94)\end{array}$ & $\begin{array}{c}-0.024 \\
(1.59)\end{array}$ & $\begin{array}{l}-0.031^{* *} \\
(3.37)\end{array}$ & $\begin{array}{c}-0.016^{*} \\
(1.72)\end{array}$ & $\begin{array}{c}-0.007 \\
(1.49)\end{array}$ \\
\hline$b_{5}: U R B A N$ & $\begin{array}{c}-0.001 \\
(0.32)\end{array}$ & $\begin{array}{c}-0.001 \\
(0.17)\end{array}$ & $\begin{array}{c}0.002 \\
(0.51)\end{array}$ & $\begin{array}{c}0.004 \\
(0.09)\end{array}$ & - \\
\hline Constant & $\begin{array}{l}0.188^{* *} \\
(3.15)\end{array}$ & $\begin{array}{c}0.145 \\
(1.01)\end{array}$ & $\begin{array}{l}0.387 * * \\
(2.77)\end{array}$ & $\begin{array}{c}0.162^{*} \\
(1.68)\end{array}$ & $\begin{array}{c}-0.017 \\
(0.36)\end{array}$ \\
\hline $\mathrm{R}^{2}$ & 0.02 & 0.03 & 0.02 & 0.01 & 0.23 \\
\hline $\begin{array}{l}N \\
\text { Test of Structural Equivalence } \\
\text { Sum of Coefficients }\end{array}$ & $\begin{array}{r}3685 \\
15.1^{* *}\end{array}$ & 935 & 1828 & 922 & 3685 \\
\hline $\begin{array}{l}\gamma_{0}+\Gamma_{1}+\Gamma_{2}+\Gamma_{\mathrm{S}} \\
\text { Test of Wage Neutrality }\end{array}$ & $\begin{array}{c}0.60 \\
19.2^{* *}\end{array}$ & $\begin{array}{r}-0.37 \\
3.47 *\end{array}$ & $\begin{array}{c}0.58 \\
10.9 * *\end{array}$ & $\begin{array}{c}2.01 \\
16.0 * *\end{array}$ & \\
\hline
\end{tabular}

\footnotetext{
${ }^{\mathrm{a}}$ Robust $t$-statistics in parentheses. One asterisk indicates significance at the .10 level. Two asterisks indicate significance at the .05 level.

${ }^{\mathrm{b}}$ Predicted, based on the Stage 1 equation below.
} 
easily rejected. ${ }^{8}$ Curiously, county population growth is insensitive to local wage growth and adjacent county wage growth in the smallest counties. Only wage growth two counties away significantly adds population in the smallest counties. For intermediate counties, wage growth in the own, adjacent, and nonadjacent counties cause home county population to increase, while home and adjacent county wage growth are most important in the largest counties. The population elasticity with respect to own county wages increases as county size increases. At the same time, wage growth outside the three-county radius (own plus adjacent plus nonadjacent) has the greatest negative effect on the smallest counties.

Common wage shocks across all markets might be expected to leave local population unchanged. However, wage changes might not be neutral if demand for local amenities varies with income or if commuting time costs do not increase equally across counties. Consequently, common wage changes across all areas may cause a given county's population to grow, decline or remain unchanged. The impact of such an equiproportional wage shock on county population growth in the sample is the sum of the population elasticities, $\gamma_{0}+\Gamma_{1}+\Gamma_{2}+\Gamma_{N}$. The summed effects are presented in Table 2 with an associated test statistic for the restriction that the sum is zero (labeled the test of wage neutrality). We reject the null hypothesis that uniform wage growth has no effect on population growth. Overall, a uniform ten percent wage increase across all regions raises population in these states by six percent. However, the largest counties grow faster than wages, while the smallest counties shrink. The implication is that equiproportional wage growth causes a population shift toward larger counties and away from smaller counties, other things equal.

The other coefficients also have interesting implications for population growth. Physical amenities are associated with more rapid population growth while higher housing costs reduce population growth. Consequently, the impact of amenities on population growth depends upon the extent to which physical amenities are capitalized in local housing costs. Holding housing costs fixed, a one-unit increase in AMENITY (equal to a 1.5 standard deviation increase) will raise population growth by 1.3 percent over 5 years. The effect is largest in the smallest counties, and very small in the largest counties. Population growth in the largest counties is also virtually insensitive to housing costs. URBAN status is generally associated with faster population growth in all counties. Counties with higher population initially also grow faster except for the largest counties.

As noted in the previous section, we expected that wage growth in the own county and perhaps in adjacent counties might be endogenous. We tested for endogenous wage growth in the following way. First, we assumed all wage growth measures were exogenous to local population growth and then tested that specification against one which assumed own county wage growth was

\footnotetext{
${ }^{8}$ This tests the joint restrictions that, other than the constant terms, the coefficients in the second-stage population growth equations are equal across small, medium and large counties. The test is distributed $\mathrm{F}(16,3660)$.

(C) Blackwell Publishers 2001.
} 
endogenous. The null hypothesis of exogenous own county wage growth was easily rejected. ${ }^{9}$ We then relaxed the assumption of exogenous wage growth in the largest adjacent county. This time the Hausman test failed to reject the null hypothesis, supporting the specification employed.

Although providing identification, the coefficient of determination $\left(R^{2}\right)$ for the first-stage Equation (11) is very small. Despite the weak fit, the results from the instrumenting equation are consistent with the local labor market model outlined above. As required by the theory, holding the employment rate constant, higher wage levels cause wages to decrease in subsequent years. The employment rate also serves as a significant identifier, but the other coefficients are not precisely estimated. ${ }^{10}$ As an additional check, we estimated the unrestricted version of the model, dropping own-county wage growth. The parameters on spatial wage growth reported in the last column of Table 2 are nearly unchanged from those in the first column. The implied local labor market still spans a three-county radius, and the roles of local amenities and housing costs are unchanged.

\section{ALTERNATIVE MEASURES OF ECONOMIC GROWTH}

Having investigated the relationship between population growth and wage growth, we consider alternative measures of economic growth that may also raise home county utility. This is particularly important if county population responds more to job growth than to growth in earnings per job. This is done by substituting measures of job growth $\left[\left(\ln \left(J_{i, t+5} / J_{i, t}\right)\right]\right.$ for wage growth in Equation (11). Alternatively, population may respond to growth in both wages and jobs. We measure wage bill growth $\left[\left(\ln \left(I_{i, t+5} / I_{i, t}\right)\right]\right.$ by growth in the total wage and salary earnings for the people working in the county.

\section{Population Growth from Spatially Differentiated Job Growth}

The results of the two-stage GLS estimation using job growth as the explanatory variable are presented in Table 3 . The second-stage model fit is similar to that in Table 2. The coefficients in the upper portion of the table represent elasticities of population growth with respect to spatially differentiated job growth. A broad brush characterization of the results is that job growth and wage growth characterize spatially differentiated economic growth similarly. As in Table 2, the implied population response to job growth over the full

${ }^{9}$ The null hypothesis of exogenous own county wage growth was rejected with a marginal significance level less than 0.01 . The null hypothesis of exogenous wage growth in the adjacent county could only be rejected at the 0.55 marginal significance level. Nevertheless, we attempted estimates that instrument both own and adjacent county wage growth. The results for the full sample were nearly identical to those in Table 2. Consistent with Table 2, there was no evidence of complementary growth beyond the adjacent county. In addition, the coefficient on residual state wage growth in the largest counties turns negative.

${ }^{10}$ Although they use a different model strategy, the results reported herein are broadly consistent with those reported in Glaeser, Scheinkman, and Shleifer (1995, Table 3). There, higher initial city income leads to lower city income growth.

(C) Blackwell Publishers 2001. 
TABLE 3: Regressions of Population Growth on Spatially Differentiated Job Growth $^{\mathrm{a}}$

\begin{tabular}{|c|c|c|c|c|c|}
\hline \multirow[t]{2}{*}{ Variables } & \multicolumn{4}{|c|}{ Estimated Coefficients and $t$-Ratios } & \multirow[b]{2}{*}{$\begin{array}{l}\text { Unrestricted, } \\
\text { Full Sample }\end{array}$} \\
\hline & $\begin{array}{c}\text { Full } \\
\text { Sample }\end{array}$ & $\begin{array}{c}\text { Lower } \\
\text { Quartile }\end{array}$ & $\begin{array}{l}\text { Middle } \\
\text { Quartiles }\end{array}$ & $\begin{array}{l}\text { Upper } \\
\text { Quartile }\end{array}$ & \\
\hline$\alpha_{0}: \ln \left(J_{0, t+5} / J_{0, t}\right)^{\mathrm{b}}$ & $\begin{array}{l}0.227^{* *} \\
(6.67)\end{array}$ & $\begin{array}{l}0.17^{* *} \\
(0.27)\end{array}$ & $\begin{array}{l}0.154^{\text {** }} \\
(3.18)\end{array}$ & $\begin{array}{l}0.528^{* *} \\
(8.78)\end{array}$ & - \\
\hline$\alpha_{1}: \ln \left(J_{1, t+5} / J_{1, t}\right)$ & $\begin{array}{l}0.070^{* *} \\
(6.37)\end{array}$ & $\begin{array}{l}0.088^{* *} \\
(2.18)\end{array}$ & $\begin{array}{l}0.080^{* *} \\
(5.12)\end{array}$ & $\begin{array}{l}0.081^{* *} \\
(4.59)\end{array}$ & $\begin{array}{l}0.070^{* *} \\
(6.50)\end{array}$ \\
\hline$\alpha_{2}: \ln \left(J_{2, t+5} / J_{2, t}\right)$ & $\begin{array}{l}0.022^{* *} \\
(2.13)\end{array}$ & $\begin{array}{c}0.009 \\
(0.38)\end{array}$ & $\begin{array}{l}0.033^{* *} \\
(2.29)\end{array}$ & $\begin{array}{c}-0.014 \\
(0.72)\end{array}$ & $\begin{array}{l}0.024 * * \\
(2.31)\end{array}$ \\
\hline$\alpha_{S}: \ln \left(J_{S, t+5} / J_{S, t}\right)^{R e s i d u a l}$ & $\begin{array}{l}-0.182^{* *} \\
(7.72)\end{array}$ & $\begin{array}{l}-0.329 * * \\
(6.96)\end{array}$ & $\begin{array}{c}-0.176^{* *} \\
(5.38)\end{array}$ & $\begin{array}{c}-0.017 \\
(0.38)\end{array}$ & $\begin{array}{l}-0.179 * * \\
(7.46)\end{array}$ \\
\hline AMENITY & $\begin{array}{l}0.013^{* *} \\
(8.75)\end{array}$ & $\begin{array}{l}0.017 * * \\
(5.50)\end{array}$ & $\begin{array}{l}0.016^{* * *} \\
(7.82)\end{array}$ & $\begin{array}{l}0.006^{* *} \\
(2.23)\end{array}$ & $\begin{array}{l}0.014^{* *} \\
(9.29)\end{array}$ \\
\hline$U R B A N$ & $\begin{array}{l}0.015^{* *} \\
(6.92)\end{array}$ & $\begin{array}{l}0.015^{* *} \\
(2.64)\end{array}$ & $\begin{array}{l}0.011^{* *} \\
(4.09)\end{array}$ & $\begin{array}{l}0.016^{* *} \\
(3.89)\end{array}$ & $\begin{array}{l}0.015^{* *} \\
(7.04)\end{array}$ \\
\hline $\ln \left(R_{t}^{H}\right)$ & $\begin{array}{c}-0.014^{* *} \\
(6.22)\end{array}$ & $\begin{array}{l}-0.015^{* *} \\
(3.47)\end{array}$ & $\begin{array}{l}-0.022^{* *} \\
(7.11)\end{array}$ & $\begin{array}{c}-0.001 \\
(0.14)\end{array}$ & $\begin{array}{l}-0.015^{* *} \\
(6.66)\end{array}$ \\
\hline $\ln \left(P_{t}\right)$ & $\begin{array}{l}0.011^{* *} \\
(8.47)\end{array}$ & $\begin{array}{r}0.007 \\
(1.55)\end{array}$ & $\begin{array}{l}0.027 * * \\
(6.76)\end{array}$ & $\begin{array}{c}-0.004 \\
(1.61)\end{array}$ & $\begin{array}{l}0.037^{* *} \\
(11.3)\end{array}$ \\
\hline Constant & $\begin{array}{c}-0.016 \\
(1.30)\end{array}$ & $\begin{array}{c}-0.012 \\
(0.48)\end{array}$ & $\begin{array}{c}-0.021 \\
(1.07)\end{array}$ & $\begin{array}{c}-0.029 \\
(1.10)\end{array}$ & - \\
\hline $\mathrm{R}^{2}$ & 0.22 & 0.14 & 0.20 & 0.19 & \\
\hline$c_{1}: \ln \left(P_{t}\right)$ & $\begin{array}{l}0.053^{* *} \\
(10.2)\end{array}$ & $\begin{array}{c}-0.007 \\
(0.35)\end{array}$ & $\begin{array}{c}-0.114 \\
(1.01)\end{array}$ & $\begin{array}{l}0.112^{* *} \\
(5.26)\end{array}$ & - \\
\hline $\mathrm{c}_{2}:\left[\ln \left(P_{t}\right)\right]^{2}$ & $\begin{array}{l}-0.003^{* *} \\
(3.75)\end{array}$ & $\begin{array}{l}0.016^{*} \\
(1.82)\end{array}$ & $\begin{array}{c}0.033 \\
(1.58)\end{array}$ & $\begin{array}{l}-0.009 * * \\
(4.64)\end{array}$ & $\begin{array}{l}-0.003^{* *} \\
(6.26)\end{array}$ \\
\hline$c_{3}: \ln \left(J_{t} / P_{t}\right)$ & $\begin{array}{l}-0.125^{* *} \\
(17.6)\end{array}$ & $\begin{array}{l}-0.137^{* *} \\
(0.16)\end{array}$ & $\begin{array}{c}-0.122^{* *} \\
(9.80)\end{array}$ & $\begin{array}{c}-0.150^{* *} \\
(9.54)\end{array}$ & $\begin{array}{l}-0.021^{* * *} \\
(4.64)\end{array}$ \\
\hline$c_{4}: \ln \left(W_{t}\right)$ & $\begin{array}{l}-0.054^{* *} \\
(5.34)\end{array}$ & $\begin{array}{c}0.014 \\
(0.73)\end{array}$ & $\begin{array}{l}-0.080^{* * *} \\
(5.26)\end{array}$ & $\begin{array}{l}-0.09 * * \\
(5.54)\end{array}$ & $\begin{array}{l}-0.011^{* *} \\
(2.17)\end{array}$ \\
\hline $\mathrm{c}_{5}: U R B A N$ & $\begin{array}{c}0.003 \\
(0.68)\end{array}$ & $\begin{array}{c}-0.016 \\
(1.64)\end{array}$ & $\begin{array}{c}-0.003 \\
(0.49)\end{array}$ & $\begin{array}{c}-0.008 \\
(1.01)\end{array}$ & $\begin{array}{l}0.015^{* *} \\
(7.04)\end{array}$ \\
\hline Constant & $\begin{array}{l}0.318^{* *} \\
(3.32)\end{array}$ & $\begin{array}{c}-0.304 \\
(1.64)\end{array}$ & $\begin{array}{l}0.744^{* *} \\
(3.32)\end{array}$ & $\begin{array}{l}0.526^{* *} \\
(3.20)\end{array}$ & $\begin{array}{c}0.035 \\
(0.72)\end{array}$ \\
\hline $\mathrm{R}^{2}$ & 0.11 & 0.11 & 0.09 & 00.14 & 0.23 \\
\hline $\begin{array}{l}N \\
\text { Test of Structural Equivalence } \\
\text { Sum of Coefficients }\end{array}$ & $\begin{array}{r}3685 \\
12.3^{* *}\end{array}$ & 935 & 1828 & 922 & 3685 \\
\hline $\begin{array}{l}\gamma_{0}+\Gamma_{1}+\Gamma_{2}+\Gamma_{\mathrm{S}} \\
\text { Test of Job Growth Neutrality }\end{array}$ & $\begin{array}{c}0.14 \\
10.2^{* *}\end{array}$ & $\begin{array}{l}-0.26 \\
8.86^{* *}\end{array}$ & $\begin{array}{l}0.09 \\
2.6\end{array}$ & $\begin{array}{c}0.58 \\
57.0^{* *}\end{array}$ & \\
\hline
\end{tabular}

${ }^{\mathrm{a}}$ Robust $t$-statistics in parentheses. One asterisk indicates significance at the .10 level. Two asterisks indicate significance at the .05 level.

${ }^{\mathrm{b}}$ Predicted, based on the Stage 1 equation below. 
sample remains positive as far as two counties away. The magnitude of the population growth response becomes smaller as the job growth becomes more distant. A 10 percent growth in jobs raises population by 2.3 percent when the jobs are in the own county, by 0.7 percent when the job growth is in an adjacent county, and 0.2 percent when the job growth is two counties away. Job growth beyond two counties distance induces outmigration, implying that the relevant county labor market includes adjacent and nonadjacent counties. ${ }^{11}$

The rest of the second-stage coefficients are similar to those in Table 2 in both sign and magnitude. The local labor market model also performs as expected, except that the fit is considerably better than in Table 2 . The model predicted that, holding wages fixed, higher employment rates in the base period would lead to slower future job growth. This prediction holds in the data. ${ }^{12}$ All in all, the instrumenting equations in Tables 2 and 3 are quite consistent with the simple sticky-wage model of local labor markets.

When we break the sample down by population size, we find that the job growth complementarities extend to nonadjacent counties for medium counties. The largest and smallest counties only gain from job growth in the own and adjacent counties. Population growth in the smallest counties is more responsive to own county job growth than to own county wage growth. Consequently, jobs are more important than wages in maintaining population in the smallest counties. However, job growth outside the two-county radius has its largest adverse impact in the smallest counties, but virtually no adverse effect in the largest counties.

As before, we test for the structural equivalence of relationships between counties and find that there are significant differences in the population growth elasticities with respect to job growth between counties of different sizes. As with wage growth, equiproportional job growth across all areas causes outmigration from the smallest counties. The population responds positively to equiproportional job growth in the more populous counties. Overall, 10 percent job growth across all markets raises population by 1.4 percent over 5 years in these states. Using sample means for jobs and population in Table 1, this suggests that an increase of 1 job raises population by 0.3 residents. This corresponds well to the Greenwood, Hunt, and McDowell (1986) study that found an additional job led to 0.5 new residents.

We reestimate the model relaxing the parametric restrictions. As shown in the last column of Table 3 , the unrestricted parameters imply a local labor market that extends to the next two counties. The signs and magnitudes of the

\footnotetext{
${ }^{11}$ Hausman's specification tests supported the exogeneity assumption for job growth outside the own county. The marginal significance level for the test of own-county exogenous job growth was below 0.0001 , but was 0.24 for exogenous adjacent county job growth.

${ }^{12}$ Glaeser, Scheinkman, and Shleifer (1995, Table 5), found higher unemployment rates led to slower growth in their sample of cities. Their results would seem to be inconsistent with standard models of labor market equilibrium. However, it is possible that their model includes cities with different equilibrium unemployment rates, a problem we are unlikely to face in our more homogeneous sample of counties.

(c) Blackwell Publishers 2001.
} 
unrestricted parameters are consistent with those of the restricted model and with those reported in Table 2 .

\section{Population Growth from Spatially Differentiated Income Growth}

The results of the estimation using growth in the wage bill $I_{0, t}=W_{0, t} J_{0, t}$ are presented in Table 4. Inserting the real wage bill in place of real wages into the specification of Equation (11) is equivalent to the assumption that $W_{0 t}$ and $\mathrm{J}_{0 t}$ have the same population elasticity $\gamma_{0}$. The model explains 24 percent of the variation in population growth. The results corroborate the findings in Tables 2 and 3, so we will not dwell on them in detail. A 10 percent increase in local county wage bill increases population by 1.7 percent. The magnitude of the effect decreases with distance, but remains positive for counties within a three-county radius. ${ }^{13}$ Beyond the three-county radius, wage bill growth competes with local population growth.

Local wage bill growth is ineffective in raising population in the smallest counties, and state wage bill growth has the largest negative effect on population growth in those counties. Consequently, wage bill growth is not neutral across counties. Common wage bill shocks across all counties lower population in the smallest counties and raise population elsewhere. Overall, the estimated population elasticity implies that 10 percent uniform aggregate wage bill growth raises population across these states by 0.7 percent over five years.

\section{Government Fiscal Policies and Population Growth}

Thus far, we have concentrated on the role of exogenous economic growth and amenities in explaining population growth. There is widespread use of government fiscal policies to alter population growth patterns, so a natural extension of our simple spatial framework is to append such policies to our list of regressors. ${ }^{14}$ The effectiveness of such policies has not been established. As Hamilton (1976) pointed out, if property taxes pay for government services whose value is capitalized by local property values, government tax and expenditure policies may have neutral effects on local population growth. Bartik (1991) found a more promising role for local and state fiscal policies, but still concluded that the costs and benefits of development policies were of similar magnitudes.

To address this issue, we appended several measures of state and local tax and expenditure policies by county. All measures were culled from the Compendium of Government Finances, which is published every five years. To avoid endogeneity between local finance measures and local population growth, we used the issue that preceded the five-year population growth period. ${ }^{15}$ The

\footnotetext{
${ }^{13}$ The marginal significance levels for tests of exogenous wage bill growth were below 0.0001 for the own-county and 0.13 for the adjacent county.

${ }^{14}$ We thank the referees for suggesting this extension.

${ }^{15}$ The Compendia contained data for 1967, 1972 and every five years to 1992 . We used 1967 state and local finance data for the population growth period 1969-1974, 1974 data for the 1974-1979 population growth, and so on.
}

(c) Blackwell Publishers 2001. 
TABLE 4: Regressions of Population Growth on Spatially Differentiated Income Growth $^{\mathrm{a}}$

\begin{tabular}{|c|c|c|c|c|c|}
\hline \multirow[t]{2}{*}{ Variables } & \multicolumn{4}{|c|}{ Estimated Coefficients and $t$-Ratios } & \multirow[b]{2}{*}{$\begin{array}{l}\text { Unrestricted, } \\
\text { Full Sample }\end{array}$} \\
\hline & $\begin{array}{c}\text { Full } \\
\text { Sample }\end{array}$ & $\begin{array}{c}\text { Lower } \\
\text { Quartile } \\
\end{array}$ & $\begin{array}{c}\text { Middle } \\
\text { Quartiles }\end{array}$ & $\begin{array}{c}\text { Upper } \\
\text { Quartile }\end{array}$ & \\
\hline$\alpha_{0}: \ln \left(I_{0, t+5} / I_{0, t}\right)^{\mathrm{b}}$ & $\begin{array}{l}0.166^{* *} \\
(6.17)\end{array}$ & $\begin{array}{c}-0.012 \\
(0.26)\end{array}$ & $\begin{array}{l}0.118^{* *} \\
(3.12)\end{array}$ & $\begin{array}{l}0.458^{* *} \\
(8.37)\end{array}$ & - \\
\hline$\alpha_{2}: \ln \left(I_{1, t+5} / I_{1, t}\right)$ & $\begin{array}{l}0.061^{* * *} \\
(7.32)\end{array}$ & $\begin{array}{c}0.039 * \\
(1.93)\end{array}$ & $\begin{array}{l}0.069 * * \\
(6.19)\end{array}$ & $\begin{array}{l}0.085^{* * *} \\
(6.28)\end{array}$ & $\begin{array}{l}0.062^{* *} \\
(7.56)\end{array}$ \\
\hline$\alpha_{3}: \ln \left(I_{2, t+5} / I_{2, t}\right)$ & $\begin{array}{l}0.019 * * \\
(2.45)\end{array}$ & $\begin{array}{c}0.013 \\
(0.75)\end{array}$ & $\begin{array}{l}0.023^{* *} \\
(2.87)\end{array}$ & $\begin{array}{l}-0.001 * * \\
(0.04)\end{array}$ & $\begin{array}{l}0.021^{* *} \\
(2.74)\end{array}$ \\
\hline$\alpha_{S}: \ln \left(I_{N, t+5} / I_{N, t}\right)^{\text {Residual }}$ & $\begin{array}{l}-0.177 * * \\
(10.4)\end{array}$ & $\begin{array}{l}-0.292^{* *} \\
(7.68)\end{array}$ & $\begin{array}{l}-0.167^{* *} \\
(7.41)\end{array}$ & $\begin{array}{c}-0.086 \\
(2.67)\end{array}$ & $\begin{array}{l}-0.174^{* *} \\
(10.1)\end{array}$ \\
\hline AMENITY & $\begin{array}{l}0.013 * * \\
(8.81)\end{array}$ & $\begin{array}{l}0.018^{* *} \\
(5.78)\end{array}$ & $\begin{array}{l}0.016^{* *} \\
(7.92)\end{array}$ & $\begin{array}{l}0.005^{* * *} \\
(2.09)\end{array}$ & $\begin{array}{l}0.014^{* * *} \\
(9.52)\end{array}$ \\
\hline$U R B A N$ & $\begin{array}{l}0.016^{* * *} \\
(7.14)\end{array}$ & $\begin{array}{l}0.015^{* *} \\
(2.64)\end{array}$ & $\begin{array}{l}0.011^{* *} \\
(4.12)\end{array}$ & $\begin{array}{l}0.015^{* *} \\
(3.85)\end{array}$ & $\begin{array}{l}0.015^{* *} \\
(7.16)\end{array}$ \\
\hline $\ln \left(R_{t}^{H}\right)$ & $\begin{array}{l}-0.012^{* *} \\
(5.31)\end{array}$ & $\begin{array}{l}-0.014^{* *} \\
(3.14)\end{array}$ & $\begin{array}{l}-0.019 * * \\
(6.36)\end{array}$ & $\begin{array}{c}-0.0003 \\
(0.08)\end{array}$ & $\begin{array}{l}-0.012^{* *} \\
(5.62)\end{array}$ \\
\hline $\ln \left(P_{t}\right)$ & $\begin{array}{l}0.012^{* *} \\
(9.55)\end{array}$ & $\begin{array}{l}0.008^{*} \\
(1.95)\end{array}$ & $\begin{array}{l}0.028^{* *} \\
(7.15)\end{array}$ & $\begin{array}{l}-0.006^{* *} \\
(2.49)\end{array}$ & $\begin{array}{l}0.037 * * \\
(11.5)\end{array}$ \\
\hline Constant & $\begin{array}{c}-0.023^{*} \\
(1.88)\end{array}$ & $\begin{array}{c}-0.020 \\
(0.78)\end{array}$ & $\begin{array}{c}-0.031 \\
(1.61)\end{array}$ & $\begin{array}{c}-0.011 \\
(0.42)\end{array}$ & \\
\hline $\mathrm{R}^{2}$ & 0.24 & 0.15 & 0.21 & 0.21 & \\
\hline $\mathrm{c}_{1}: \ln \left(P_{t}\right)$ & $\begin{array}{l}0.058^{* *} \\
(8.15)\end{array}$ & $\begin{array}{c}0.010 \\
(0.34)\end{array}$ & $\begin{array}{c}-0.215 \\
(-1.37)\end{array}$ & $\begin{array}{l}0.107^{* * *} \\
(3.68)\end{array}$ & - \\
\hline $\mathrm{c}_{2}:\left[\ln \left(P_{t}\right)\right]^{2}$ & $\begin{array}{l}-0.003^{* *} \\
(2.79)\end{array}$ & $\begin{array}{c}0.013 \\
(1.04)\end{array}$ & $\begin{array}{c}0.053 \\
(1.86)\end{array}$ & $\begin{array}{l}-0.008 * * \\
(2.96)\end{array}$ & $\begin{array}{l}-0.003^{* *} \\
(6.56)\end{array}$ \\
\hline $\mathrm{c}_{3}: \ln \left(J_{t} / P_{t}\right)$ & $\begin{array}{l}-0.157 * * \\
(16.3)\end{array}$ & $\begin{array}{l}-0.186^{* * *} \\
(8.52)\end{array}$ & $\begin{array}{l}-0.148^{* *} \\
(-8.52)\end{array}$ & $\begin{array}{l}-0.165^{* * *} \\
(-8.74)\end{array}$ & $\begin{array}{l}-0.020^{* * *} \\
(4.32)\end{array}$ \\
\hline $\mathrm{c}_{4}: \ln \left(W_{t}\right)$ & $\begin{array}{l}-0.081^{* *} \\
(5.81)\end{array}$ & $\begin{array}{l}-0.005 \\
(-0.19)\end{array}$ & $\begin{array}{l}-0.113^{* *} \\
(5.49)\end{array}$ & $\begin{array}{l}-0.113^{* *} \\
(5.01)\end{array}$ & $\begin{array}{l}-0.009^{*} \\
(1.91)\end{array}$ \\
\hline $\mathrm{c}_{5}: U R B A N$ & $\begin{array}{l}-0.005^{* *} \\
(0.77)\end{array}$ & $\begin{array}{c}-0.019 \\
(1.00)\end{array}$ & $\begin{array}{c}-0.003 \\
(0.35)\end{array}$ & $\begin{array}{c}-0.008 \\
(0.76)\end{array}$ & $\begin{array}{l}0.015^{* *} \\
(7.16)\end{array}$ \\
\hline Constant & $\begin{array}{l}0.507 * * \\
(3.91)\end{array}$ & $\begin{array}{c}-0.206 \\
(0.79)\end{array}$ & $\begin{array}{l}1.14^{* *} \\
(3.64)\end{array}$ & $\begin{array}{l}0.690^{* *} \\
(3.07)\end{array}$ & $\begin{array}{c}0.012 \\
(0.25)\end{array}$ \\
\hline $\mathrm{R}^{2}$ & 0.09 & 0.10 & 0.07 & 0.10 & 0.25 \\
\hline $\begin{array}{l}N \\
\text { Test of Structural Equivalence } \\
\text { Sum of Coefficients }\end{array}$ & $\begin{array}{r}3685 \\
13.0 * *\end{array}$ & 935 & 1828 & 922 & 3685 \\
\hline $\begin{array}{l}\gamma_{0}+\Gamma_{1}+\Gamma_{2}+\Gamma_{S} \\
\text { Test of Wage Bill Growth Neutra }\end{array}$ & $\begin{array}{r}0.07 \\
\text { ity } 4.5^{* *}\end{array}$ & $\begin{array}{l}-0.17 \\
14.8 * *\end{array}$ & $\begin{array}{l}0.04 \\
1.09\end{array}$ & $\begin{array}{c}0.46 \\
48.8 * *\end{array}$ & \\
\hline
\end{tabular}

${ }^{\mathrm{a}}$ Robust $t$-statistics in parentheses. One asterisk indicates significance at the .10 level. Two asterisks indicate significance at the .05 level.

${ }^{\mathrm{b}}$ Predicted, based on the Stage 1 equation below. 
measures include local tax revenue per capita, local outstanding debt per capita, local per capita expenditures on education, roads, and other services, and per capita expenditures paid for by state and federal sources. All measures were in $\log$ form. We would expect local taxes to lower residential utility while local expenditures and outside infusion of funds should raise residential utility.

The results of the unconstrained form of the earlier models, incorporating local government fiscal variables, are reported in Table 5. The estimation allows for correlated errors across counties at one point in time and across time for individual counties. As is clear, adding the local fiscal variables does not affect the magnitude or significance of the coefficients on variables included before. Sign reversals only occur in two instances where coefficients are virtually zero in magnitude and significance. Complementary growth is still shown to span a radius of three counties. As before, a unit increase in AMENITY raises population growth by 1.4 percent every five years, an increase in residential costs lowers population growth modestly, and urban areas and more populated areas grow faster.

Adding the fiscal variables does help to explain population growth: the chi-square test restricting the fiscal coefficients to zero is easily rejected. However, the Hamilton assumption of neutral local fiscal policy coefficients (tax, debt, education, roads and other local expenditures) summed to -0.001 and the sum was not significantly different from zero. The infusion of state or federal funds did raise local population growth, but the elasticity was very small, 0.01. The implication of Table 5 is that locally financed government services have a negligible effect on local population growth.

\section{IMPLICATIONS}

This paper uses spatially differentiated economic growth to determine the relationship between counties in terms of complementary or competing growth. We found that complementary economic growth spans a radius of three counties for all but the largest counties. Those counties experience complementary growth with adjacent counties. These spatial patterns are robust to differences in estimation procedure, included variables, and measure of economic growth. Given the generally uniform structure and size of the counties in our study, this result is consistent with studies that define the local labor market by a one-way commuting time of up to an hour. ${ }^{16}$

We find that the largest counties have a comparative advantage in attracting migrants. When economic growth occurs in all regions, the smallest counties get smaller and the largest counties get larger. The smallest counties benefit less from their own growth, and lose more from growth occurring elsewhere. Renkow (1996) found that rural wages were more sensitive to local labor market shocks than were urban wages. This is consistent with our finding that rural population growth is less sensitive to local wage shocks. If rural labor supply is

\footnotetext{
${ }^{16}$ See So, Orazem, and Otto (2001).
} 
TABLE 5: Replication of Spatially Differentiated Models Incorporating Government Fiscal Variables ${ }^{\mathrm{a}}$

\begin{tabular}{|c|c|c|c|c|c|c|}
\hline & \multicolumn{6}{|c|}{ Growth Indicator } \\
\hline & \multicolumn{2}{|c|}{ Wages } & \multicolumn{2}{|c|}{ Jobs } & \multicolumn{2}{|c|}{ Wage Bill } \\
\hline & 1 & 2 & 1 & 2 & 1 & 2 \\
\hline$\Gamma_{1}:$ Adjacent County & $\begin{array}{l}0.104^{* *} \\
(6.47)\end{array}$ & $\begin{array}{l}0.103^{* *} \\
(6.56)\end{array}$ & $\begin{array}{l}0.068^{* * *} \\
(6.56)\end{array}$ & $\begin{array}{l}0.068^{* *} \\
(6.76)\end{array}$ & $\begin{array}{l}0.057 * * \\
(8.03)\end{array}$ & $\begin{array}{l}0.056^{* *} \\
(8.19)\end{array}$ \\
\hline \multicolumn{7}{|l|}{$\Gamma_{2}$ : Nonadjacent } \\
\hline County & $\begin{array}{l}0.081^{* *} \\
(4.55)\end{array}$ & $\begin{array}{l}0.083^{* *} \\
(4.70)\end{array}$ & $\begin{array}{l}0.032^{* *} \\
(3.18)\end{array}$ & $\begin{array}{l}0.030 \text { ** } \\
(3.05)\end{array}$ & $\begin{array}{l}0.026 * * \\
(3.56)\end{array}$ & $\begin{array}{l}0.024^{* *} \\
(3.47)\end{array}$ \\
\hline$\Gamma_{S}:$ State & $\begin{array}{l}-0.221^{* *} \\
(6.73)\end{array}$ & $\begin{array}{c}-0.193^{* * *} \\
(5.77)\end{array}$ & $\begin{array}{l}-0.150^{* * *} \\
(7.18)\end{array}$ & $\begin{array}{l}-0.140^{* * *} \\
(6.78)\end{array}$ & $\begin{array}{l}-0.139 * * \\
(9.16)\end{array}$ & $\begin{array}{l}-0.128^{* * *} \\
(8.37)\end{array}$ \\
\hline AMENITY & $\begin{array}{l}0.014^{* *} \\
(5.42)\end{array}$ & $\begin{array}{l}0.014^{* *} \\
(5.37)\end{array}$ & $\begin{array}{l}0.013^{* *} \\
(5.00)\end{array}$ & $\begin{array}{l}0.012^{* *} \\
(4.90)\end{array}$ & $\begin{array}{l}0.013^{* *} \\
(5.15)\end{array}$ & $\begin{array}{l}0.013^{* *} \\
(5.10)\end{array}$ \\
\hline$U R B A N$ & $\begin{array}{l}0.023^{* *} \\
(6.25)\end{array}$ & $\begin{array}{l}0.022^{* *} \\
(6.27)\end{array}$ & $\begin{array}{l}0.021^{* * *} \\
(5.72)\end{array}$ & $\begin{array}{l}0.021^{* *} \\
(5.75)\end{array}$ & $\begin{array}{l}0.021 * * \\
(5.82)\end{array}$ & $\begin{array}{l}0.021^{* *} \\
(5.84)\end{array}$ \\
\hline $\ln \left(R_{t}^{H}\right)$ & $\begin{array}{l}-0.018^{* *} \\
(10.1)\end{array}$ & $\begin{array}{l}-0.018^{* * *} \\
(8.47)\end{array}$ & $\begin{array}{l}-0.022^{* *} \\
(11.9)\end{array}$ & $\begin{array}{l}-0.022^{* * *} \\
(9.70)\end{array}$ & $\begin{array}{l}-0.019 \text { ** } \\
(10.8)\end{array}$ & $\begin{array}{l}-0.019^{* *} \\
(8.85)\end{array}$ \\
\hline $\ln \left(P_{t}\right)$ & $\begin{array}{l}0.027^{* *} \\
(7.16)\end{array}$ & $\begin{array}{l}0.027^{* *} \\
(5.59)\end{array}$ & $\begin{array}{l}0.025^{* *} \\
(6.14)\end{array}$ & $\begin{array}{l}0.026^{* *} \\
(5.04)\end{array}$ & $\begin{array}{l}0.025^{* *} \\
(6.46)\end{array}$ & $\begin{array}{l}0.026^{* *} \\
(5.10)\end{array}$ \\
\hline$\left[\ln \left(P_{t}\right)\right]^{2}$ & $\begin{array}{c}-0.003^{* *} \\
(4.19)\end{array}$ & $\begin{array}{l}-0.002^{* *} \\
(3.39)\end{array}$ & $\begin{array}{l}-0.003^{* * *} \\
(3.50)\end{array}$ & $\begin{array}{l}-0.002^{* * *} \\
(2.81)\end{array}$ & $\begin{array}{l}-0.003^{* *} \\
(3.81)\end{array}$ & $\begin{array}{l}-0.002^{* *} \\
(3.10)\end{array}$ \\
\hline $\ln \left(J_{t} / P_{t}\right)$ & $\begin{array}{l}0.012^{* * *} \\
(1.67)\end{array}$ & $\begin{array}{l}0.018^{* *} \\
(2.45)\end{array}$ & $\begin{array}{l}0.015^{* *} \\
(2.21)\end{array}$ & $\begin{array}{l}0.022^{* *} \\
(2.86)\end{array}$ & $\begin{array}{l}0.016 * * \\
(2.37)\end{array}$ & $\begin{array}{l}0.022^{* *} \\
(2.97)\end{array}$ \\
\hline $\ln \left(W_{t}\right)$ & $\begin{array}{r}0.007 \\
(0.88)\end{array}$ & $\begin{array}{c}0.003 \\
(0.45)\end{array}$ & $\begin{array}{c}0.003 \\
(0.053)\end{array}$ & $\begin{array}{c}-0.003 \\
(0.44)\end{array}$ & $\begin{array}{c}0.003 \\
(0.42)\end{array}$ & $\begin{array}{l}-0.0001 \\
(0.03)\end{array}$ \\
\hline $\ln (\operatorname{Tax})$ & & $\begin{array}{c}-0.009 \\
(1.49)\end{array}$ & & $\begin{array}{c}-0.008 \\
(1.33)\end{array}$ & & $\begin{array}{c}-0.008 \\
(1.43)\end{array}$ \\
\hline $\ln ($ Debt $)$ & & $\begin{array}{l}0.004^{* * *} \\
(2.80)\end{array}$ & & $\begin{array}{l}0.004^{* * *} \\
(2.61)\end{array}$ & & $\begin{array}{l}0.004^{* *} \\
(2.62)\end{array}$ \\
\hline $\ln ($ Education $)$ & & $\begin{array}{c}0.014 \\
(1.62)\end{array}$ & & $\begin{array}{l}0.016^{*} \\
(1.73)\end{array}$ & & $\begin{array}{l}0.015^{*} \\
(1.68)\end{array}$ \\
\hline $\ln$ (Roads) & & $\begin{array}{c}-0.005^{*} \\
(1.81)\end{array}$ & & $\begin{array}{c}-0.006^{*} \\
(1.90)\end{array}$ & & $\begin{array}{c}-0.005^{*} \\
(1.67)\end{array}$ \\
\hline $\ln ($ Other Expenditures $)$ & & $\begin{array}{l}-0.006^{* * *} \\
(2.93)\end{array}$ & & $\begin{array}{l}-0.007^{* * *} \\
(3.11)\end{array}$ & & $\begin{array}{l}-0.006^{* *} \\
(2.90)\end{array}$ \\
\hline $\ln ($ State and Federal $)$ & & $\begin{array}{l}0.010 * * \\
(2.91)\end{array}$ & & $\begin{array}{l}0.010^{* * *} \\
(2.66)\end{array}$ & & $\begin{array}{l}0.009 \text { ** } \\
(2.62)\end{array}$ \\
\hline Constant & $\begin{array}{c}0.0001 \\
(0.001)\end{array}$ & $\begin{array}{c}-0.017 \\
(0.24)\end{array}$ & $\begin{array}{c}0.036 \\
(0.52)\end{array}$ & $\begin{array}{c}0.062 \\
(0.85)\end{array}$ & $\begin{array}{l}.00001 \\
(0.001)\end{array}$ & $\begin{array}{c}0.025 \\
(0.34)\end{array}$ \\
\hline $\mathrm{R}^{2 \mathrm{~b}}$ & 0.23 & 0.26 & 0.23 & 0.26 & 0.25 & 0.27 \\
\hline$N$ & 3685 & 3685 & 3685 & 3685 & 3685 & 3685 \\
\hline Government Impact $\chi^{2}(6)$ & & $51.6 * *$ & & $48.8^{* *}$ & & $46.86^{* *}$ \\
\hline Local Fiscal Neutrality & & & & & & \\
\hline Sum: Local Fiscal & & -0.001 & & -0.001 & & -0.001 \\
\hline $\operatorname{Impact} \chi^{2}(1)$ & & 0.07 & & 0.002 & & 0.02 \\
\hline
\end{tabular}

${ }^{\mathrm{a}}$ Maximum likelihood controlling for random effects for each county and time period. $t$-statistics in parentheses. One asterisk indicates significance at the .10 level. Two asterisks indicate significance at the .05 level.

${ }^{\mathrm{b}}$ From the least-squares estimate of the specification. 
less elastic, demand shocks will cause larger wage reactions in rural markets than in urban markets.

What do these results tell us about economic policy options? These results suggest that economic development strategies should be regionally based. By coordinating their efforts, counties can take advantage of the spillover benefits that exist between counties. If agglomeration economies are important, these results suggest that they will depend upon the concentration and mix of firms and workers across an area that includes the own county, its neighbors, and the neighbors' neighbors. ${ }^{17}$ Agglomeration economies do not require that each county have the same mix and concentration of firms and workers as long as the mix and concentration occurs somewhere in the commuting region.

In formulating policy for the smallest counties, it appears that jobs are more important than wages in stimulating population growth. Therefore, it may be counterproductive to concentrate on creation of high-wage jobs as opposed to policies that encourage job growth when designing development policies for rural counties. Once again, rural counties also benefit from job and income growth in their neighboring counties, so cooperative development efforts among rural counties are most likely to be successful. Local exogenous amenities related to climate or geological features have a small positive effect on population growth. However, rental costs retard population growth. To the extent that housing costs reflect naturally occurring local amenities, the net effect of the amenities will be reduced. Finally, locally financed government services do not appear to be a promising avenue for attracting new residents. The net effect of local government tax and expenditure policies on population growth is virtually zero.

\section{REFERENCES}

Adams, Charles F., Howard B. Fleeter, Mark Freeman, and Yul Kim. 1994. "Flight From Blight Revisited," School of Public Policy and Management, Ohio State University.

Alonso, William. 1964. Location and Land Use. Cambridge, MA: Harvard University Press.

Bartik, Timothy J. 1991. Who Benefits from State and Local Economic Development Polices? Kalamazoo, MI: W. E. Upjohn Institute.

Benabou, Roland. 1993. "Workings of a City: Location, Education, and Production," The Quarterly Journal of Economics, 108, 619-655.

Blanchflower, David G. and Andrew J. Oswald. 1994. The Wage Curve. Cambridge, MA: MIT Press. Blomquist, Glen C., Mark C. Berger, and John P. Hoehn. 1988. "New Estimates of the Quality of Life in Urban Areas," American Economic Review, 78, 89-107.

Boarnet, Marlon. 1994. "The Monocentric Model and Employment Location," Journal of Urban Economics, 36, 79-97.

Carlino, Gerald A. and Edwin S. Mills. 1987. "The Determinants of County Growth," Journal of Regional Studies, 27, 39-54.

\footnotetext{
${ }^{17}$ Quigley (1998), Glaeser (1998) and Krugman (1998) review the literature on agglomeration economies. Larger cities are argued to benefit from lower costs of transportation, information, marketing, and input acquisition and from smaller exposure to cyclical fluctuations. These cost advantages cause populations to concentrate in cities, and also may allow these concentrated areas to grow more rapidly than sparsely populated areas.
}

C B Blackwell Publishers 2001. 
Carrington, William J. 1996. "The Alaskan Labor Market During the Pipeline Era," Journal of Political Economy, 104, 186-218.

Clark, David E. and Christopher Murphy. 1996. "Countywide Employment and Population Growth: An Analysis of the 1980s," Journal of Regional Science, 36, 235-256.

Fisher, Peter S. and Alan H. Peters. 1998. Industrial Incentives: Competition Among American States and Cities. Kalamazoo, MI: W.E. Upjohn Institute.

Gaile, G.L. 1980. "The Spread-Backwash Concept," Regional Studies, 14, 15-25.

Glaeser, Edward L. 1998. "Are Cities Dying?” Journal of Economic Perspectives, 12, 139-160.

Glaeser, Edward L., Jose A. Scheinkman, and Andrei Shleifer. 1995. "Economic Growth in a Cross-Section of Cities," Journal of Monetary Economics, 36, 117-143.

Greenwood, Michael J., Gary L. Hunt, and John M. McDowell. 1986. "Migration and Employment Change: Empirical Evidence of the Spatial and Temporal Dimensions of the Linkage," Journal of Regional Science, 26, 223-234.

Hamilton, Bruce. 1976. "Capitalization of Interjurisdictional Differences in Local Tax Prices," American Economic Review, 66, 743-753.

Henry, Mark S., David Barkley, and Shuming Bao. 1997. "The Hinterland's Stake in Metropolitan Growth: Evidence from Selected Southern Regions,” Journal of Regional Science, 37, 479-501.

Krugman, Paul. 1998. "Space: The Final Frontier," Journal of Economic Perspectives, 12, 161-174.

McMillen, Daniel P. and Larry D. Singell. 1992. "Work Location, Residence Location, and the Intraurban Wage Gradient," Journal of Urban Economics, 32, 195-213.

Mills, Edwin S. 1967. “An Aggregative Model of Resource Allocation in Metropolitan Areas,” American Economic Review, 57, 197-210.

Muth, Richard F. 1969. Cities and Housing: The Spatial Pattern of Urban Residential Land Use. Chicago, IL: University of Chicago Press.

Quigley, John M. 1998. "Urban Diversity and Economic Growth," Journal of Economic Perspectives, $12,127-138$.

Renkow, Mitch. 1996. "Income Non-Convergence and Rural Urban Earnings Differentials: Evidence from North Carolina," Southern Economic Journal, 62, 1017-1028.

Roback, Jennifer. 1982. "Wages, Rents, and the Quality of Life," Journal of Political Economy, 90, 1257-1278.

So, Kim S., Peter F. Orazem, and Daniel M. Otto. 2002. "The Effects of Housing Prices, Wages, and Commuting Time on Joint Residential and Job Location Choices," American Journal of Agricultural Economics.

Voith, Richard P. 1991. "Capitalization of Local and Regional Attributes into Wages and Rents: Differences Across Residential, Commercial and Mixed-Use Communities," Journal of Regional Science, 31, 127-145.

1993. "Changing Capitalization of CBD-Oriented Transportation Systems: Evidence from Philadelphia, 1970-1988,” Journal of Urban Economics, 33, 361-376.

1998. "Do Suburbs Need Cities?” Journal of Regional Science, 38, 445-464.

White, Michelle. 1988. "Location Choice and Commuting Behavior in Cities with Decentralized Employment," Journal of Urban Economics, 24, 129-152. 